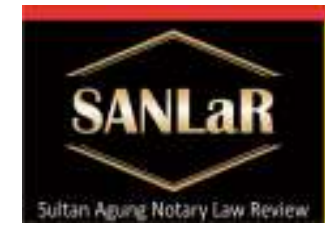

Volume 3 No.4, December 2021
Sultan Aqung

Notary Law Review

The Inheritance Grants without...(Takib Wilman Hakim, Akhmad Khisni \& Amin Purnawan)

\title{
The Inheritance Grants without Approval of Any Heirs
}

\author{
Takib Wilman Hakim ${ }^{*}$, Akhmad Khisni ${ }^{* *}$ and Amin Purnawan ${ }^{* * *}$ \\ ${ }^{*}$ Faculty of Law, Universitas Islam Sultan Agung (UNISSULA) Semarang, E-mail: \\ wilmanhakim55@gmail.com
}

${ }^{* *}$ Faculty of Law, Universitas Islam Sultan Agung (UNISSULA) Semarang, E-mail: amin.p@unissula.ac.id

${ }^{* * *}$ Faculty of Law, Universitas Islam Sultan Agung (UNISSULA) Semarang, E-mail:
khisni@unissula.ac.id

Abstract. The purpose of this study was to find out and analyze the legal considerations of the panel of judges to adjudicate a dispute over the Deed of Grant of Land Rights to one of the prospective heirs without the consent of the other prospective heirs in the Cirebon District Court Decision Number. 18/Pdt.G/2017/PN.Cbn. To find out and analyze the Certainty of the Deed of Grant of Land Rights without the Approval of Prospective Heirs Based on the Compiled of Islamic Law. The method used by the researcher is Empirical Jurisdiction and The specifications in this study are descriptive-analytical. Based on the results of the study that Legal Considerations of the Panel of Judges to adjudicate the Dispute on the Deed of Grant of Land Rights to One of the Prospective Heirs without the Approval of the Other Prospective Heirs it is appropriate to cancel the grant because if it is related to the legislation on grants, it has violated Article $211 \mathrm{KHI}$ which is supported by considering evidence in the form of a certificate of distribution of land/agricultural/housing assets, the statement of the grant cannot be adjusted to the original and the object of the case determined as inheritance cannot be accepted because the inheritance has never been divided with other heirs. Certainty of the Deed of Grant of Land Rights without the Approval of Prospective Heirs Based on the Compiled of Islamic Law on grant in Article 200 of the Compilation of Islamic Law is an act carried out in the context of delivering an item/object from the grantor to the grantee and the goods delivered are his own property.

Keywords: Grant; Heir; Inheritance; Non-Approval.

\section{Introduction}

Society is always changing and the only thing that makes the difference is the 
nature or degree of change. Changes in society are visible and some are invisible, some are fast and some are slow, and there are changes that involve fundamental things in people's lives, this is because humans are not only a collection of human history but are arranged in various groups. and institutionalization, so that the interests of the community are not the same, if there are common interests then it encourages the emergence of grouping among them, then legal regulations are formed to regulate human interests. ${ }^{1}$

For this reason, Islamic law is required to be accommodating to the problems of the people without losing its basic principles. The reforms are based on assumptions or views that are clearly influenced by the situation and social environment, that Islamic law as a certain reality and environment is not in accordance with and even deviates from the real Islam, as well as in terms of inheritance issues. ${ }^{2}$

A grant is an agreement that is born because of an agreement that is often used to distribute assets before the occurrence of inheritance, thus the agreement will also give birth to rights and obligations in the field of property law, where the party who entered into the agreement will provide a grant voluntarily without compensation for giving it to the other party. He wishes, for the benefit of the grantor, to whom he has promised or bound himself, with a guarantee in the form of assets owned and will be owned by the grantee. ${ }^{3}$

It can be said that a grant is a legal act that intends to transfer ownership rights intentionally, not in a state of illness, or by coercion and with an agreement to be transferred to another party without expecting a return for the element of affection, the transfer of rights is carried out when the right holder is still alive on the object/asset that already exists with consent and qabul, grants include acts of a cash nature, except for will grants. ${ }^{4}$

Based on the problems above, the objectives of this study are as follows: To find out and analyze the Legal Considerations of the Panel of Judges to adjudicate the Dispute on the Deed of Grant of Land Rights to One of the Prospective Heirs without the Approval of the Other Prospective Heirs. To find out and analyze the Certainty of the Deed of Grant of Land Rights without the Approval of Prospective Heirs Based on the Compiled of Islamic Law.

\footnotetext{
${ }^{1}$ Abdul Manan, (2005), Aspek-Aspek Pengubah Hukum, Jakarta: Kencana Prenada Media Group, p. 71

${ }^{2}$ Azyumardi Asra, (2000), Akar-Akar Historis Pembaharuan Hukum Islam Neo Sufisme Abad ke 1112 Dalam Tasauf, Jakarta: Yayasan Wakaf Paramadina, p. 179

${ }^{3}$ Gunawan Widjaja Kartini Muljadi, (2003), Perikatan Yang Lahir Dari Perjanjian, Jakarta: Raja Grafindo Persada, p. 2.

${ }^{4}$ Boedi Harsono, (2003), Hukum Agraria Indonesia (Sejarah Pembentukan Undang- Undang Pokok Agrari. Isi \& Pelaksanaannya), Jakarta: Djambatan, p. 333.
} 


\section{Research Methods}

The method used in this research is empirical juridical. The specifications used in this research are descriptive-analytical, which is intended to provide data that may be studied about a situation or other symptoms. ${ }^{5}$ The sources and types of data in this study are primary data obtained from field studies with interviews with Clerk of Cirebon District Court. And secondary data obtained from literature studies related to the theory of legal certainty and the theory of justice.

\section{Results and Discussion}

\subsection{Legal Considerations of the Panel of Judges to adjudicate the Dispute on the Deed of Grant of Land Rights to One of the Prospective Heirs without the Approval of the Other Prospective Heirs}

Proof can be done in authentic writing or by writing under the hand. ${ }^{6}$ Underhand writing or also known as an underhand deed is made in a form not determined by law, without intermediaries or not in the presence of an authorized public official. ${ }^{7}$ However, the purpose of making it is also intended as evidence and if that happens then it must be supported by other evidence. The private deed has the power of proof as long as the parties admit it or there is no denial from the other party or from one of the parties ${ }^{8}$ then the deed under the hand has perfect evidentiary power as an authentic deed. ${ }^{9}$

Not only is the notary responsible for making the mandatory will, he is also responsible for its implementation. In the implementation of this mandatory will, the notary must carry out what the testator or testator wants and explain all the heirs' will to all heirs. A notarial deed that is disputed before a court hearing in a civil case with a deed made by a notary, it is more appropriate to present a notary who made the deed as an expert witness. ${ }^{10}$

Normative legal certainty is when a regulation is made and promulgated with certainty because it regulates clearly and logically. It is clear in the sense that it does not cause doubt (multi-interpretation) and is logical. It is clear in the sense that it becomes a norm system with other norms so that it does not clash and

\footnotetext{
${ }^{5}$ Soerjono Soekanto \& Sri Mamuji, (2001), Penelitian Hukum Normatif suatu tinjauan singkat, Jakarta: Raja Grafindo Persada, p. 43.

${ }^{6}$ Article 1867 of the Civil Code

${ }^{7}$ Article 1874 of the Civil Code.

${ }^{8}$ M.Ali Budiarto, (2005), Kompilasi Kaidah Hukum Putusan Mahkamah Agung, Hukum Perdata Setengah Abad, Jakarta: Swa Justitia, p. 145

${ }^{9}$ Article 1875 of the Civil Code.

${ }^{10}$ Pricilia Yuliana Kambey, 2013, Peran Notaris Dalam Proses Peradilan Pidana, Jurnal, Lex Et Societatis, Volume I Nomor 2, p. 30
} 
does not cause a conflict of norms. Legal certainty refers to the application of a clear, permanent, consistent and consequent law whose implementation cannot be influenced by subjective circumstances. Certainty and justice are not merely moral demands, but factually characterize the law. ${ }^{11}$

According to adherents of this school, although the rule of law or the application of the law feels unfair and does not provide great benefits for the majority of the community, it is not a problem as long as legal certainty can be realized. Law is synonymous with certainty. ${ }^{12}$

The heirs who own several parcels of land (immovable objects) as the inheritance of the heirs, in the settlement of the distribution of their inheritance often experience problems/problems, especially in the process of changing their names to the heirs, before finally being divided equally into the names of each heir. This does not escape the limited issuance of a Certificate of Inheritance. ${ }^{13}$

Legal Considerations of the Panel of Judges to adjudicate the Dispute on the Deed of Grant of Land Rights to One of the Prospective Heirs without the Approval of the Other Prospective Heirs it is appropriate to cancel the grant because if it is related to the legislation on grants it has violated Article $211 \mathrm{KHI}$ which is supported by considering evidence in the form of a certificate of distribution of land/agricultural/housing assets, the statement of the grant cannot be adjusted to the original and the object of the case which is determined as inheritance cannot be accepted because the inheritance has never been divided with other heirs, then based on Article 171 letters (c), (d), (e), in conjunction with Article 185 of the KHI, the judge's decision has correctly applied the inconcerto law to the decision taking into account the heirs who are entitled to the object of the case based on their respective shares.

Legal Considerations of the Panel of Judges to adjudicate the Dispute on the Deed of Grant of Land Rights to One of the Prospective Heirs without the Approval of the Other Prospective Heirs analyzed using legal certainty theory that basically the principle of legal certainty emphasizes law enforcement based on formal evidence, meaning that a violation caused by an act can only be said to violate if certain written rules apply. On the other hand, according to the principle of justice, acts that are not fair, disgraceful, violate propriety and so on

\footnotetext{
${ }^{11}$ Cst Kansil, Christine, S.T Kansil, Engeline R, Palandeng and Godlieb N Mamahit, (2009), Kamus Istilah Hukum, Jakarta, p. 385

${ }^{12}$ Achmad Ali, (2009), Menguak Teori Hukum (Legal Theory) \& Teori Peradilan (Judicial Prudence): Termasuk Interpretasi Undang-Undang (Legisprudence), Jakarta: Kencana Prana Media Group, p. 286

${ }^{13}$ Umi Setyawati, Amin Purnawan, Akta Penegasan Keterangan Waris Sebagai Pengganti Surat Keterangan Waris Dalam Pengurusan Balik Nama Waris Di Kantor Pertanahan Kota Semarang, Jurnal Akta Unissula, Vol 5 No 1 March 2018
} 
can be considered as violations for the sake of upholding justice, even though formally reviewed there are no written rules/statutory regulations that prohibit it.

\subsection{Certainty of the Deed of Grant of Land Rights without the Approval of Prospective Heirs Based on the Compiled of Islamic Law}

$\mathrm{KHI}$ and the Civil Code both have a written legal basis. Basically in the two legal systems, namely the $\mathrm{KHI}$ and the Civil Code, a will is a gift that is dependent on the event of the death of the person who wills, whether the gift is with or without the consent of the person who will be given or who will receive the will. ${ }^{14}$

Inheritance often causes problems in the family. There are many risks that arise associated with this inheritance. If it is not wise to react to it, conflicts in the family can occur and result in estrangement and even the breaking of family ties. There are several things related to inheritance that need to be considered so that the sale or purchase of inheritance is not problematic later. ${ }^{15}$

The concept of justice contained in the Qur'an, which has been interpreted by Quraish Shihab and Sayyid Qutub, it is said that the concept of justice is fair in the sense of being equal, fair in the sense of being balanced, fair in the sense of paying attention to individual rights and giving rights. This right belongs to everyone who has the right to receive it and is fair in the sense that is attributed to Allah SWT. In Islam, the command to be fair without discrimination, must be enforced in giving to prospective heirs, even to infidels, Muslims are ordered to be fair.

The distribution of inheritance using a notarial deed is an alternative method of inheritance distribution in addition to using court institutions which are commonly used by the Indonesian people in the distribution of inheritance. Similar to court decisions, the deed made by a notary is intended to explain the distribution of inheritance to anticipate problems that may arise in the future. Based on positive Indonesian law, there are several ways to determine the distribution of inheritance. The first, as already mentioned, is through a court decision, the second is through a notary through the distribution of the deed of separation and distribution of inheritance. Both have the same legal force so that if a family already has only one or uses only one method, then the legal force is already strong. Both methods have equally strong legal force. Article 15 paragraph (1) of the UUJN explains that one of the powers of a Notary is to make a deed in general, with limitations as long as: (a) No exceptions are made to

\footnotetext{
${ }^{14}$ Adam Lukmanto, Munsharif Abdul Chalim, 2017, Tinjauan Hukum \& Akibatnya Terhadap Wasiat Tanpa Akta Notaris Ditinjau Dari Kompilasi Hukum Islam \& Kitab Undang-Undang Hukum Perdata, Jurnal Akta Unissula, Vol. 4. No. 1, 29-32

15 Ferri Adhi Purwantono, Akhmad Khisni, 2018, Tinjauan Yuridis Implikasi Perjanjian Jual-Beli Dalam Keluarga Yang Dibuat Oleh Notaris Terhadap Kedudukan Ahli Waris, Jurnal Akta Unissula, Vol 5 No 1
} 
other officials stipulated by law. (b) The community of deeds that must be made or authorized to make authentic deeds regarding all actions, agreements, and provisions required by law or desired by the person concerned. (c) Regarding the legal subject (person or legal entity) for whose interest the deed was made or desired by the interested party. (d) Authority regarding the place, where the deed was made, this is in accordance with the domicile and area of office of the Notary. (e) Regarding the time of making the deed, ${ }^{16}$

The provisions of the Compilation of Islamic Law can certainly refer to the hadiths of the Prophet Muhammad, including the hadith narrated by the congregation from Sa'id bin Abi Wa Qash when he came to the Prophet asking for instructions about his wealth which he would give in charity / will because he was the only one daughter. In the dialogue, the Messenger of Allah (SAW) replied that he bequeathed $1 / 3$ (one third) of the property, which is a very maximum amount because the amount will not harm the acquisition of other heirs. ${ }^{17}$

The sources of law that are used as guidelines for law enforcers (judges), practitioners, and so on in addition to the written laws mentioned above are the fatwas of scholars, whether written in classical fiqh books or modern figh books. These sources to this day are complementary materials in the process of multiplying Islamic Law. ${ }^{18}$

Inheritance is the essence of causality (the main cause) in owning property, while property is the bandage of life, both individually and universally. With that treasure the soul of life always revolves. Inheritance law is a law that regulates the transfer of assets left by someone who dies and the consequences for his heirs. In principle, only rights and obligations in the legal field of wealth/property can be inherited. ${ }^{19}$

The compilation of Islamic law is a major success for Indonesian Muslims in the New Order government, according to M. Yahya Harahap, the objectives of the compilation of the $\mathrm{KHI}$ are: (a) to systematically formulate Islamic law in Indonesia in a concrete manner; (b) to serve as the basis for the application of Islamic law in the religious courts; (c) the nature of the compilation with a national perspective that will be treated for the entire Indonesian Muslim community if a dispute arises in the trial of the religious court; (d) at the same time it will be able to foster a more uniform enforcement of legal certainty in the traffic association of the Islamic community.

\footnotetext{
${ }^{16}$ Setya Qodar Al-Haolandi, Sukarmi, 2018, Peran Notaris Dalam Pembagian Waris Berdasarkan Hak Waris Barat Dengan Peran Pengadilan Agama Dalam Pembagian Waris Berdasarkan Hak Waris Islam, Jurnal Akta Unissula, Vol 5 No 1

${ }^{17}$ Muliana, Akhmad Khisni, 2017, Akibat Hukum Akta Hibah Wasiat Yang Melanggar Hak Mutlak Ahli Waris (Legitieme Portie), Jurnal Akta Unissula, Vol. 4 No. 4

${ }^{18}$ Syarief Husien, Akhmad Khisni, 2018, Hukum Waris Islam Di Indonesia (Studi Perkembangan Hukum Kewarisan Dalam Kompilasi Hukum Islam \& Praktek Di Pengadilan Agama ), Jurnal Akta Unissula, Vol 5 No 1

${ }^{19}$ Effendi Perangin, (2008), Hukum Waris, Jakarta: Raja Grafindo Persada, p. 3.
} 
Certainty of the Deed of Grant of Land Rights without the Approval of Prospective Heirs Based on the Compiled of Islamic Law on grant in Article 200 of the Compilation of Islamic Law is an act carried out in the context of delivering an item/object from the grantor to the grantee and the goods delivered are his own property. In this case, the Defendant could not prove the truth of the procession (ijab qobul) of grant implementation to the object of dispute. In this case the consideration of the Panel of Judges is correct, because it is in line with the opinion of legal experts on the Book of I'anah Ath-Thalibin juz III page 41 which means: "The pillars of grants in a special sense are the same as the pillars of buying and selling, namely there are three: the grantor, the object being donated, and the consent qobul. "And in accordance with the syar'i argument contained in the Book of Bajuri juz II page 62 which means: "Gifts are not valid unless the consent and qobul are pronounced."

Apart from not being able to prove the truth of the procession (ijab qobul) of the implementation of the grant by the Defendant, it can be proven in the facts of the trial that the object of dispute from the beginning until now is still controlled by the Plaintiffs and the Plaintiff also pays the tax, so that the element of own ownership of the goods/objects is not fulfilled.

The certainty of the Deed of Grant of Land Rights without the Approval of Prospective Heirs Based on the Compiled of Islamic Law was analyzed using the theory of justice that because according to the case there were parties who felt that the distribution of inheritance according to the faraidh law was ignored. Because the principle of justice in the distribution of inheritance in Islamic law can basically be said that gender differences do not determine inheritance rights in Islam. This means that men and women have the same strong right to inherit.

\section{Conclusion}

Legal Considerations of the Panel of Judges to adjudicate the Dispute on the Deed of Grant of Land Rights to One of the Prospective Heirs without the Approval of the Other Prospective Heirs it is appropriate to cancel the grant because if it is related to the legislation on grants it has violated Article $211 \mathrm{KHI}$ which is supported by considering evidence in the form of a certificate of distribution of land/agricultural/housing assets, the statement of the grant cannot be adjusted to the original and the object of the case which is determined as inheritance cannot be accepted because the inheritance has never been divided with other heirs, then based on Article 171 letters (c), (d), (e), in conjunction with Article 185 of the $\mathrm{KHI}$, the judge's decision has correctly applied the inconcerto law to the decision taking into account the heirs who are entitled to the object of the case based on their respective shares and Certainty of the Deed of Grant of Land Rights without the Approval of Prospective Heirs Based on the Compiled of Islamic Law on grant in Article 200 of the Compilation of Islamic Law is an act carried out in the context of delivering an item/object from the 
grantor to the grantee and the goods delivered are his own property. In this case, the Defendant could not prove the truth of the procession (ijab qobul) of grant implementation to the object of dispute. In this case, the consideration of the Panel of Judges is correct, because it is in line with the opinion of legal experts on the Book of I'anah Ath-Thalibin juz III page 41 which means: "The pillars of grants in a special sense are the same as the pillars of buying and selling, namely there are three: the grantor, the object being donated, and the consent qobul. " And in accordance with the syar'i argument contained in the Book of Bajuri juz II page 62 which means: "Gifts are not valid unless the consent and qobul are pronounced."

\section{References}

Journals:

[1] Adam Lukmanto, Munsharif Abdul Chalim, 2017, Tinjauan Hukum \& Akibatnya Terhadap Wasiat Tanpa Akta Notaris Ditinjau Dari Kompilasi Hukum Islam \& Kitab Undang-Undang Hukum Perdata, Jurnal Akta Unissula, Vol. 4. No. 1, 29-32

[2] Ferri Adhi Purwantono, Akhmad Khisni, 2018, Tinjauan Yuridis Implikasi Perjanjian Jual-Beli Dalam Keluarga Yang Dibuat Oleh Notaris Terhadap Kedudukan Ahli Waris, Jurnal Akta Unissula, Vol 5 No 1

[3] Muliana, Akhmad Khisni, 2017, Akibat Hukum Akta Hibah Wasiat Yang Melanggar Hak Mutlak Ahli Waris (Legitieme Portie), Jurnal Akta Unissula, Vol. 4 No. 4

[4] Pricilia Yuliana Kambey, 2013, Peran Notaris Dalam Proses Peradilan Pidana, Jurnal, Lex Et Societatis, Volume I Nomor 2, p. 30

[5] Setya Qodar Al-Haolandi, Sukarmi, 2018, Peran Notaris Dalam Pembagian Waris Berdasarkan Hak Waris Barat Dengan Peran Pengadilan Agama Dalam Pembagian Waris Berdasarkan Hak Waris Islam, Jurnal Akta Unissula, Vol 5 No 1

[6] Syarief Husien, Akhmad Khisni, 2018, Hukum Waris Islam Di Indonesia (Studi Perkembangan Hukum Kewarisan Dalam Kompilasi Hukum Islam \& Praktek Di Pengadilan Agama), Jurnal Akta Unissula, Vol 5 No 1

[7] Umi Setyawati, Amin Purnawan, Akta Penegasan Keterangan Waris Sebagai Pengganti Surat Keterangan Waris Dalam Pengurusan Balik Nama Waris Di Kantor Pertanahan Kota Semarang, Jurnal Akta Unissula, Vol 5 No 1 March 2018 
Books:

[1] Abdul Manan, (2005), Aspek-Aspek Pengubah Hukum, Jakarta: Kencana Prenada Media Group

[2] Achmad Ali, (2009), Menguak Teori Hukum (Legal Theory) \& Teori Peradilan (Judicial Prudence): Termasuk Interpretasi Undang-Undang (Legisprudence), Jakarta: Kencana Prana Media Group

[3] Azyumardi Asra, (2000), Akar-Akar Historis Pembaharuan Hukum Islam Neo Sufisme Abad ke 11- 12 Dalam Tasauf, Jakarta: Yayasan Wakaf Paramadina

[4] Boedi Harsono, (2003), Hukum Agraria Indonesia (Sejarah Pembentukan Undang- Undang Pokok Agrari. Isi \& Pelaksanaannya), Jakarta: Djambatan

[5] Cst Kansil, Christine, S.T Kansil, Engeline R, Palandeng and Godlieb N Mamahit, (2009), Kamus Istilah Hukum, Jakarta

[6] Effendi Perangin, (2008), Hukum Waris, Jakarta: Raja Grafindo Persada

[7] Gunawan Widjaja Kartini Muljadi, (2003), Perikatan Yang Lahir Dari Perjanjian, Jakarta: Raja Grafindo Persada

[8] M.Ali Budiarto, (2005), Kompilasi Kaidah Hukum Putusan Mahkamah Agung, Hukum Perdata Setengah Abad, Jakarta: Swa Justitia

[9] Soerjono Soekanto \& Sri Mamuji, (2001), Penelitian Hukum Normatif suatu tinjauan singkat, Jakarta: Raja Grafindo Persada 